\title{
Study on factors influencing customer leaving an apparel store without a purchase
}

DOI: 10.35530/IT.070.04.1556

Studiu asupra factorilor care influenţează decizia de cumpărare a articolelor de îmbrăcăminte

În vânzarea cu amănuntul, mulți clienți părăsesc magazinul fără a face vreo achiziție din cauza diferiților factori. Un studiu detaliat a fost realizat pentru a înțelege factorii care influențează decizia clientului de a părăsi magazinul, fără o achiziție. În cadrul studiului, datele au fost colectate de la 1838 de clienți ai unui magazin de îmbrăcăminte și au fost analizate statistic folosind metoda de analiză a factorilor. Analiza factorilor a grupat 21 de variabile care influențează factori importanți, și anume: marfa, serviciile și personalul de vânzări. Printre acestea, motivele legate de marfă precum disponibilitatea produselor la modă, marca preferată și calitatea s-au dovedit a fi factori importanţi care influențează clienții. În cadrul studiului, au rezultat concluzii pentru comercianți. Studiul sistematic al factorilor care influențează clientul să renunțe la o achiziție a fost limitat la vânzarea cu amănuntul a articolelor de îmbrăcăminte. Prin urmare, lucrarea de față va fi foarte utilă pentru comercianții de îmbrăcăminte, cu scopul de a satisfice clienții într-o manieră mai eficientă.

Cuvinte-cheie: nemulțumirea clienților, renunțare, mărfuri, indisponibilitatea produsului, îmbrăcăminte

\section{Study on factors influencing customer leaving an apparel store without a purchase}

In retailing, many customers quit the store without a purchase due to various factors. In order to understand the influencing factors on customer leaving store without a purchase, a detailed study was conducted. For the study, data was collected from 1838 customers at an apparel store and statistically analyzed using factor analysis method was performed, to identify reasons for a customer leaving a store without a purchase. Factor analysis grouped 21 influencing variables into three major factors namely - Merchandise, Service, and Sales personnel. Among them, merchandise-based reasons like availability of fashionable products; preferred brand and quality were found to be a major factor influencing customers to leave the store without making a purchase. Based on the findings, implications for retailers were drawn. The systematic study of the factors influencing the customer to drop a purchase was limited in apparel retailing. Hence the present work will be very useful for the apparel retailers to satisfy customers in a better manner.

Keywords: customer dissatisfaction, defection, merchandise, product non-availability, apparel

\section{INTRODUCTION}

Apparel retailing in India predominantly was unorganized. In recent years, in apparel retailing due to the entry of Foreign Direct Investment and many organized players namely like Zara, H\&M, Reebok entering the business, apparel retail is transiting from unorganized to organized [1-2]. Thus a new challenge faced by Indian apparel retailer is to retain existing customers and withstand the tough competition by the organized new entrants. In order to retain an existing customer, the retailer needs to understand consumer purchase behavior and satisfy consumer needs, this scenario is same in various sectors of retailing too such as restaurants [3] and banking [4].

In all the sectors, researchers state that customer tastes are heterogeneous and individual customer needs vary from time to time, they also stress the need to understand customer behavior and satisfy them. Customer satisfaction is one of the key factors, as satisfied customers are likely to recommend to five or six people, while dissatisfied ones have a tendency to share their experience with other ten people [5]. Some studies [6] pointed out that retailers instead of spending heavily on new customers can work a strategy to retain existing customers which can increase the footfall conversion rate i.e., the ratio of a number of customers making a purchase versus the number of customers walk-in. In order to increase the footfall conversion rate retailers can introduce loyalty programs, understanding existing customers want etc. Compared to other retail sectors, footfall conversion rate is very less in apparel retailing. A current study [7] has documented the effect of traffic on conversion rate in apparel.

In apparel retailing, few research works have been carried out to understand customer-purchasing behavior. Current studies [8-9] have investigated and revealed that service, merchandise, value for money, location, staff are the factors influencing the store choice among Indian apparel shoppers in single branded and multi-branded store. The importance of store image attributes on consumer purchase behavior was studied by specialists [10]. In their study, the results showed that merchandise and clientele were highly important dimensions that affect store image. Studies [11-13] have analyzed the effect of store patronage customer satisfaction on consumer purchase behavior. Their study suggests that factors like 
service, product selection, brand, assortment and quality have a high influence on consumer purchase behavior. Authors [14] studied the major influencing factors for customers satisfaction and loyalty and found that trust has a positive effect on satisfaction and loyalty.

The behavior of consumers when their expected product is not available in the store was thoroughly studied by specialists [15]. Their study resulted that customer reacts by switching store or quitting or canceling the purchase, due to non-availability of their expected product in the store. These reactions by the customers lead to loss to the retailers [16]. A 5 percent reduction in the customer defection rate can increase profits by 25 to 85 percent, depending on the industry [17].

From the above literature on apparel retailing it is understood that though there are various studies to understand customer patronage, service quality, store image, customers reactions to non-product availability but there are very few [18] or rather no systematic study in apparel retailing that integrated study on merchandise/assortment based factors affecting consumer behavior reactions and reasons from the retailer for such situations.

In this context, this study aims to study the factors influencing customer no purchase decision. And also tries to identify reasons from the retailer's side on why that problem has happened. Thus, a retailer can identify reasons for the customer no purchase decision and also find out the reason from the retailer's side and curb that activity or improve certain services to avoid customer attrition.

\section{MATERIAL AND METHODS}

A questionnaire was designed and validated by [19] was used to collect data on consumer purchase behavior. Primarily the questionnaire was framed to analyze customers who buy, who do not buy, and who are browsers in the chosen retail store. The variables which affect the consumer purchase behavior are given in table 1 .

Another questionnaire which was developed and validated by authors [20] was used in the study to understand the reasons from the retailer for product nonavailability.

Store profile: The study was carried out in one reputed apparel retailer in Chennai, a metropolitan city, where heterogeneous customers shop. The store area is 11500 sq.ft, it caters to Men's, Women's, and Kids wear. The survey was carried out in the month of October because, in Chennai, it is the time when people tend to shop more apparel for the festival. The survey was carried out continuously for 30 days in all working hours from 10.00 am to $8.00 \mathrm{pm}$ of the day.

Survey: Primary data is collected using questionnaire by conducting store exit survey on all working hours of the day and all days of a week to have a full representation of the population. Respondents were chosen based on the systematic selection i.e. every

\begin{tabular}{|c|l|}
\hline \multicolumn{2}{|c|}{ STUDIED VARIABLES } \\
\hline \multicolumn{1}{|c|}{ Vable 1} \\
\hline SI. no. & \multicolumn{1}{|c|}{ Variables } \\
\hline 1 & Fashion garments \\
\hline 2 & Store personnel fast in service \\
\hline 3 & Branded merchandise \\
\hline 4 & Sstore personnel polite \& friendly \\
\hline 5 & Merchandise quality \\
\hline 6 & Waiting time \\
\hline 7 & Variety \\
\hline 8 & Checkout payment \\
\hline 9 & Guarantee \\
\hline 10 & Operating hours are not convenient \\
\hline 11 & Pricing \\
\hline 12 & Practical \& illogical shelf layout \\
\hline 13 & Competitive pricing \\
\hline 14 & Store temperature \\
\hline 15 & Coordinating merchandise \\
\hline 16 & Elevator \\
\hline 17 & Size \\
\hline 18 & Sales promotion \\
\hline 19 & Preferred color \\
\hline 20 & Adjustments \\
\hline 21 & Store personnel understanding needs \\
\hline
\end{tabular}

fifth customer was who exit the retail store was surveyed. The efficiency of the questionnaire was also tested using the response rate. Each day after the customer survey was over, the product which the customers expected to purchase but did not make a purchase were discussed with the store manager. For every product, the store manager gave the reason for product non-availability at that time.

Data Analysis: The primary data collected through survey were analyzed using factor analysis to understand the factors influencing consumer-purchasing behavior. SPSS was used to perform factor analysis. Respondents' demographics were also analyzed. The data on respondents who buy, who do not buy, who came for browsing was also analyzed.

\section{RESULTS AND DISCUSSION}

Response rate: The response rate for the survey is shown in table 2. From the table, it can be observed that among 1838 customers approached for the survey only 1665 accepted to respond which is $90.53 \%$. This indicates a good response rate. Further, from the table 2, it can be observed that out of 1665 respondents, 442 respondents did not make purchase their preferred item which is around $27 \%$. The intentions of respondents who do not purchase their preferred products were analyzed from the questionnaire and are given in table 3 . The five intentions mentioned in table 3 were switch store, postpone, item switch, cancel and brand switch. Out of 442 respondents, around $68 \%$ opted to switch store, $22 \%$ opted to 
postpone, $8 \%$ switched their item, i.e. instead of buying their most preferred product they bought some other product, $1 \%$ cancelled their purchase i.e they decided not to buy and $1 \%$ switched from their preferred brand to another brand, because they could not find their brand. From the above analysis, it is very clear that switching store gained higher value followed by postponing the purchase, item switch, canceling the purchase, and switching the brand. This $68 \%$ is a higher value, which could lead to a loss. This may be due to the fact that the respondents have a choice of finding another retailer to make their purchase. In this condition, the retail store must understand the needs of the consumer and satisfy the customers. The other $22 \%$ which opted to postpone may come to the same store later or may differ their purchase, which is also a loss, however only $8 \%$ of the respondents are ready to switch their item which is not a loss to the retailer, but the proportion is very less. Hence in the retailing process, customers have choices to get their products from their competitors; retailers must understand customers' needs and retain their customers.

That is they have gained $68 \%$ and $22 \%$ respectively, this indicates that the retailer must understand and satisfy the needs of the customers. Otherwise, this will become a big loss for the retailer, as $68 \%$ of customers who could not buy their product are switching store, i.e. they buy immediately from a competitor, and this will also spoil the retailer's reputation through bad word of mouth.

\begin{tabular}{|l|c|}
\hline \multicolumn{2}{|c|}{ RESPONSE RATE } \\
\hline \multicolumn{2}{|c|}{ Respo 2 } \\
\hline No. of customers approached & $\begin{array}{c}\text { Number of } \\
\text { respondents }\end{array}$ \\
\hline No. of respondents accepted to answer & 1838 \\
\hline No. of respondents without a purchase & 1665 \\
\hline
\end{tabular}

\begin{tabular}{|l|c|c|}
\hline \multicolumn{2}{|c|}{ STUDIED CUSTOMER INTENTION } \\
\hline \multicolumn{1}{|c|}{ Customer intention } & $\begin{array}{c}\text { Number of } \\
\text { respondents }\end{array}$ & $\begin{array}{c}\text { Frecvency } \\
\text { (\%) }\end{array}$ \\
\hline Switch store & 298 & 68 \\
\hline Postpone & 98 & 22 \\
\hline Item switch & 37 & 8 \\
\hline Cancel & 5 & 1 \\
\hline Brand switch & 4 & 1 \\
\hline $\begin{array}{l}\text { Total no. of respondents } \\
\text { without a purchase }\end{array}$ & 442 & 100 \\
\hline
\end{tabular}

Influential factors: This analysis investigates why the customer leaves the store empty-handed. The factor analysis grouped the 21 variables into three major factors. Among these three factors, factor 1 has the effect up to $27.68 \%$, factor 2 has an effect up to $9.9 \%$ and factor 3 also has an effect up to $9.5 \%$, whose Eigen values were greater than 1.

The factor analysis grouped 21 variables into 3 factors based on factor loading. In case of factor one, the variables such as current fashion goods, availability of size, color, brand, coordinates, quality of the merchandise, variety, guarantee and appropriate pricing resulted with higher loading ranges between 0.750 and 0.432 . It represents that these variables come from this factor 1 have a high influence on customer leaving the store empty-handed. And these variables are all related to merchandise and are termed as merchandise. Similarly, the factor 2 and 3 were termed as sales person and service.

Table 4

\begin{tabular}{|l|c|c|c|}
\hline \multicolumn{4}{|c|}{ ROTATED COMPONENT MATRIX } \\
\hline \multirow{2}{*}{ Items } & \multicolumn{3}{c|}{ Factors loadings } \\
\hline & 1 & 2 & 3 \\
\hline Fashion & 0.458 & & \\
\hline Brand & 0.432 & & \\
\hline Quality & 0.750 & & \\
\hline Variety & 0.678 & & \\
\hline Guarantee & 0.557 & & \\
\hline Price & 0.487 & & \\
\hline Competitor & 0.464 & & \\
\hline Coordinate & 0.584 & & \\
\hline Size & 0.492 & & \\
\hline Colour & 0.691 & & \\
\hline Understand & & 0.798 & \\
\hline Fast & & 0.842 & \\
\hline Polite & & 0.764 & \\
\hline Wait & & 0.623 & \\
\hline Payment & & & 0.735 \\
\hline Hours & & & 0.538 \\
\hline Layout & & & 0.609 \\
\hline Temperature & & & 0.439 \\
\hline Elevator & & & 0.654 \\
\hline Promo & & & 0.505 \\
\hline Adjustments & & & \\
\hline
\end{tabular}

Among the 3 factors, factor 1 has the highest value i.e. $27.68 \%$. Therefore, this retailer should mainly concentrate on factor 1 , the customer's reasons to switch store are major because of merchandise. From this table it is also clear that customers just do not purchase the available product, they are very smart, knowledgeable, and they analyze before a purchase. Thus, the study points out that merchandise is a most influencing factor for a customer leaving the storeempty-handed along with sales personnel and service. This accounts for $9.905 \%$ and 9.517\% respectively.

The Cronbach alpha an indicator of internal consistency was calculated as 0.785 for the 21 items, thus indicating a high degree of internal consistency. 
Table 5 also attributed. This also caused problems like shelf not being refilled on time. Thus, the table 5 clearly points out the retailer's reasons for a customer leaving the store without a purchase and a major reason is attributed to inefficient sales forecast.

\section{CONCLUSION}

Customers' leaving the store empty-handed was thoroughly studied in this study. From this study it was observed that $26.47 \%$ quit store without making a purchase, retailers should address to improve the $\%$ of profit and positive word of mouth. Merchandise based factors were the major factor cited by the respondents. From another survey for the retailers, the reasons for product non-availability was also studied and the major reason identified was inefficient sales forecast, i.e it can be attributed to lack of understanding of what the customer want. So retailers can make use of these kinds of the survey and take corrective actions to satisfy the customer and improve the conversion rate. This study is not void of limitations, as mentioned earlier, the study does not include other variables like personal reasons for leaving a store without a purchase. The cumulative \% accounted for only 47.107 and the remaining variables were not found to have a major influence.

\section{BIBLIOGRAPHY}

[1] Fatima, D., Impact of organised retailing on unorganised retailing in India 2015, 2013, shodhganga.inflibnet.ac.in/.../ 1/dinar\%20fatima_formatted_full_thesis.pdf

[2] Srivastava, R.K., Changing retail scene in India, In: Int J Retail Distrib Manag, 2008, 36, pp. 714-721, doi:https://doi.org/10.1108/09590550810890957

[3] Josiam, B.M., Malave, R., Foster, C., Baldwin W., Assessing quality of food, service and customer experience at a restaurant: the case of a student-run restaurant in the USA, Hosp Mark Consum Behav Creat Memorab Exp 2017

[4] Van Huy, L., Long, P., O'Connor, A., Tuyen, P.D., The development and measurement of a Customer Satisfaction Index (E-CSI) in electronic banking: An application to the Central Vietnam Region, In: Int J Strategy Decis Sci, 2017, 8, pp. 45-58, doi:10.4018/IJSDS.2017070102

[5] Zairi, M., Managing customer dissatisfaction through effective complaints management systems, In: TQM Mag, 2000, 12, pp. 331-337. doi:10.1108/09544780010341932

[6] Gallo, A., The value of keeping the right customers, In: Harv Bus Rev, 2014, 29

[7] Perdikaki, O., Kesavan, S., Swaminathan, J.M., Effect of traffic on sales and conversion rates of retail stores, In: Manuf Serv Oper Manag, 2012, 14, pp. 145-162, doi:10.1287/msom.1110.0356

[8] Basu, R., Guin, K.K., Sengupta, K., Do apparel store formats matter to Indian shoppers?, In: Int J Retail Distrib Manag, 2014, 42, pp. 698-716, doi:10.1108/IJRDM-03-2013-0065

[9] Tripathi, G., Dave, K., Store format choice and relationship quality in apparel retail: A study of young and earlymiddle-aged shoppers in New Delhi region, In: J Retail Consum Serv, 2013, 20, pp. 479-487, doi:https://doi.org/10.1016/j.jretconser.2013.04.003

[10] Van Noordwyk, H. S. J., Du Preez, R., Visser, E. M., Importance of apparel store image attributes: Perceptions of female consumers, In: SA J Ind Psychol, 2006, 32, pp. 49-62

[11] Pan, Y., Zinkhan, G. M., Determinants of retail patronage: A meta-analytical perspective, In: J Retail, 2006, 82, pp. 229-243, doi:10.1016/j.jretai.2005.11.008

[12] Fernie, J., Corcoran, L., Responses to out-of-stocks and on-shelf availability in UK fashion retailing, In: Int Rev Retail Distrib Consum Res, 2011, 21, pp. 309-322, doi:10.1080/09593969.2011.588715

[13] Popa, A., Pelau, C., Differences in the clothing brand perception depending on generation, In: Industria Textila, 2016, 67, 4, p. 260

[14] Hui, S. L., Yee, R. W. Y., Relationship among interpersonal relationship, customer satisfaction and brand loyalty in Fashion Retailing Industry, In: Res J Text Appar, 2015, 19, pp. 65-72, doi:10.1108/RJTA-19-01-2015-B007

[15] Campo, K., Gijsbrechts, E., Nisol, P., Towards understanding consumer response to stock-outs, In: J Retail, 2000, 76, pp. 219-242

[16] Battista, C., Falsini, D., Scarabotti, I., Schiraldi, M. M., Quantifying shelf-out-of-stock in fashion \& apparel retail stores, In: Proc. Conf. "Breaking Barriers Res. Ind., 2011 
[17] Matzler, K., Mooradian, T. A., King, L., Linder,A., Converting browser to buyers: an approach to measure and increase conversion rates in retailing, In: Innov Mark, 2010, 6, pp. 34-38

[18] Balakrishnan, R., A study of non conversion of customer footfall at Marks \& Spencer's (Mary St. Dublin), Dublin Business School, 2007

[19] Sundararaman, B., Ramalingam, N., Development and validation of a survey instrument to understand the factors influencing customer-leaving store empty-handed, In: TAGA, 2018, 14, pp. 1764-1776

[20] Vasconcellos, L. H. R., Sampaio, M., The stockouts study: an examination of the extent and the causes in the São Paulo supermarket sector, In: BAR-Braz Adm Rev, 2009, 6, pp. 263-79

\section{Authors: \\ SUNDARARAMAN BANUMATHY ${ }^{1}$, RAMALINGAM NEELAKANDAN²}

${ }^{1}$ Department of Apparel and Fashion Design, PSG College of Technology, Peelamedu, Coimbatore 641004, India e-mail: mailbanu@rediffmail.com

${ }^{2}$ Department of Textile Technology, Anna University, Guindy, Chennai 600 025, India,

e-mail: neelakandanr@annauniv.edu

Corresponding author:

SUNDARARAMAN BANUMATHY

e-mail: mailbanu@rediffmail.com 